PRODUTO \& PRODUÇÃO, vol. 21, n.3, p.53-75. 2020

P P

\title{
Padronização da Utilização de Embalagem por Meio das Ferramentas da Qualidade
}

\section{Standardization of Package Use Through Quality Tools}

\author{
Franscisco Evangelista da Silva \\ Centro Universitário Farias Brito - (FBuni), Especialista em Engenharia de Produção, Brasil \\ email: evangelista.atende@hotmail.com
}

\author{
Mauricio Johnny Loos \\ Centro Universitário Farias Brito - (FBuni), Pós-Doutorado em Gestão Industrial \\ email:mauricioloos@hotmail.com
}

\section{Resumo}

Em um mercado cada vez mais competitivo, as organizações vêm buscando reduzir o custo de fabricação de seus produtos e serviços prestados, por meio do aperfeiçoamento de seus processos, eliminando atividades que não acrescentar valor ao produto, identificando os gargalos e solucionando suas causas raízes. A utilização de determinadas técnicas e ferramentas da qualidade tornou-se um mecanismo indispensável para as organizações, na busca pela solução de problemas e melhoria contínua dos processos organizacionais. Neste contexto, este artigo tem como objetivo padronizar a utilização de embalagens por meio das ferramentas da qualidade. A abordagem metodológica utilizada neste trabalho foi a pesquisa-ação, a qual fundamenta-se em cinco etapas: Planejamento do Projeto, Coletas dos Dados, Analise dos Dados, Implementações das ações e Avaliações dos Resultados. O trabalho foi realizado em uma fábrica de medidores de energia elétrica, localizada no estado do Ceará. A partir dos resultados apresentados neste trabalho, pode-se concluir que a empresa pesquisada obteve ganhos significativos, pois reduziu e padronizou a variedade de itens de embalagens utilizadas em seus produtos, diminuiu o dead stock no almoxarifado, reduziu o custo com embalagens, aperfeiçoou o gerenciamento de embalagens no processo produtivo e aumentou o poder de barganha na aquisição de embalagens. Com base nestes ganhos apresentados, pôde-se concluir que a empresa se tornou mais competitiva no mercado.

Palavras-chave: Ferramentas da qualidade, Padronização, Embalagem, Papelão ondulado.

Recebido em 04/05/2020. Aceito em 22/06/2020. 


\begin{abstract}
In an increasingly competitive market, organizations have sought to reduce the cost of manufacturing their products and services, by improving their processes, eliminating activities that do not add value to the product, identifying bottlenecks and solving their root causes. The use of certain quality techniques and tools has become an indispensable mechanism for organizations, in the search for problem solving and continuous improvement of organizational processes. In this context, this article aims to standardize the use of packaging using quality tools. The methodological approach used in this work was action research, which is based on five stages: Project Planning, Data Collection, Data Analysis, Implementation of actions and Evaluation of Results. The work was carried out in an electricity meter factory, located in the state of Ceará. From the results presented in this work, it can be concluded that the researched company obtained significant gains, since it reduced and standardized the variety of packaging items used in its products, decreased the dead stock in the warehouse, reduced the cost with packaging, improved the packaging management in the production process and increased bargaining power in the acquisition of packaging. Based on these gains presented, it was concluded that the company has become more competitive in the market.
\end{abstract}

Keywords: Quality tools, standardization, packaging, corrugated board.

\title{
1. Introdução.
}

Para as empresas que buscam se destacar ou se manter competitiva diante de seus concorrentes, isso independente do mercado em que estejam inseridas, precisa-se buscar meios a fim de reduzir os custos em seus processos organizacionais que não agregam valor aos seus clientes, levando em consideração o processo ponta a ponta, ou seja, desde primeira etapa da produção até o entrega do produto ao cliente final, sempre mantendo a qualidade dos serviços prestados ou produtos.

Conforme a ABINEE (Associação Brasileira da Indústria Elétrica e Eletrônica) o cenário econômico do setor eletroeletrônico aponta em seus principais indicadores que nos últimos quatro anos, houve um aumento significativo do faturamento nas indústrias das áreas elétrica e eletrônica. Diante deste cenário, as empresas deste setor estão buscando serem mais competitivas diante de seus concorrentes, lutando por cada fatia deste mercado que a cada ano vem crescendo, para isso, tornouse necessário às organizações eliminarem seus desperdícios na produção, melhorar a utilização dos recursos produtivos, diminuir a variabilidade de seus processos e aumentar a capacidade produtiva.

Neste contexto, este artigo tem como objetivo padronizar a utilização de embalagens por meio das ferramentas da qualidade. A abordagem metodológica utilizada neste trabalho foi a pesquisaação, a qual fundamenta-se em cinco etapas: Planejamento do Projeto, Coletas dos Dados, Análise dos Dados, Implementações das ações e Avaliações dos Resultados.

A empresa estudada para realização da pesquisa ação proposta neste trabalho é uma das grandes referências no mercado de medidores de energia elétrica do Brasil, sendo líder no mercado brasileiro deste segmento com capacidade para produção de 3 milhões de medidores por ano, atendendo uma gama de produtos que abrange clientes residenciais, comerciais e industriais.

As embalagens possuem um papel importante para garantir a facilidade no armazenamento, manuseio e na proteção do produto durante o processo produtivo e logístico, permitindo a redução do tempo de realização de tarefas e os custos relacionados ao produto (ROCHA, 2015). Por isso, é tão importante se obter embalagens padronizadas a fim de melhorar o gerenciamento do controle de itens em estoque, evitar erros no manuseio no processo de embalagem e manter o máximo de produtos utilizando a mesma embalagem, além disso, esta prática poderá aumentar o poder de barganha no ato da compra da embalagem, pois, ao invés de comprar vários itens de embalagens em pequenas quantidades, compra-se um volume maior de um único item. 
Tendo em vista a importância que a padronização pode contribuir para a empresa tornar-se mais competitiva no mercado em que está inserido, este trabalho teve como objetivo padronizar a utilização de embalagens na empresa objeto deste estudo.

Para cumprir seus objetivos, este trabalho está estruturado da seguinte forma: apresenta inicialmente uma revisão da literatura, seguida pelos procedimentos metodológicos, após, a discussão dos resultados, e por fim, suas conclusões.

\section{2 .Revisão da Literatura.}

Nesta seção é apresentada uma revisão da literatura sobre a aplicação das ferramentas da qualidade, padronização, embalagens e papelão ondulados, utilizadas para a análise e resolução do problema do estudo apresentado.

\subsection{Ferramentas da Qualidade}

Quando se pretende implementar um projeto de melhoria em uma organização, independentemente do ramo de atuação, primeiramente é necessário realizar a identificação do problema, fazer as observações necessárias, fazer a coleta de dados, analisar as possíveis causas e eliminar a origem do problema, implementar as ações de melhoria e, por último, verificar os resultados (CARPINETTI, 2012). Para isso existem ferramentas da Qualidade que ajudam em cada etapa do projeto.

Segundo Maiczuk et al. (2013), as organizações utilizam as ferramentas da qualidade como método para melhorar seus processos, e que as mesmas estão sendo utilizadas não somente na área operacional, mas também na área administrativa, ajudando na tomada de decisão, coleta de dados e evidenciando fatos.

Existem inúmeras ferramentas da qualidade aplicadas nas organizações que possuem a capacidade em identificar e analisar problemas e ajudam a encontrar a solução destes. Baseadas em algumas literaturas, as sete ferramentas da qualidade mais utilizadas nas organizações são as seguintes: diagrama de Ishikawa, histograma, diagrama de Pareto, carta de controle, folha de verificação, diagrama de dispersão e fluxograma, conforme ilustradas na figura 1.

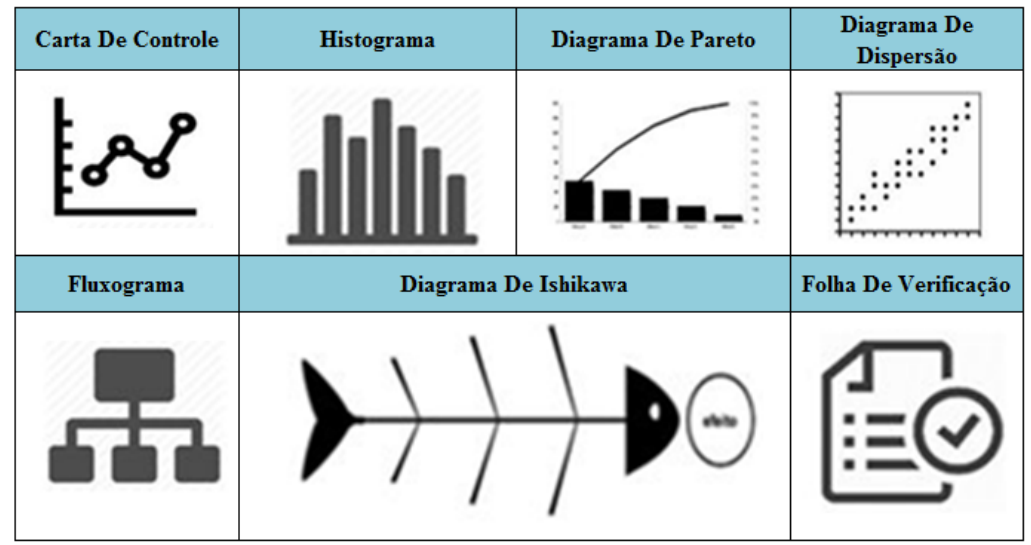

Figura 1 - As setes ferramentas da Qualidade

Fonte: Adaptado pelo autor (2019). 


\subsubsection{Brainstorming.}

Segundo Soares e Brito (2014) é uma ferramenta que pode-se aplicar para se ter uma grande ideia, por meio de um monte de ideias, e com isso, buscar a solução para um determinado problema. Este termo também é bastante conhecido como "tempestade de ideias", ende em que um grupo de pessoas se reúne e discute as possíveis causas que contribuem para a ocorrência do problema (GODOY, 2001).

Conforme Behr, Moro e Estabel (2008), para se obter bons resultados por meio de um brainstorming, deve-se seguir as seguintes etapas:

- $\quad$ Etapa 01 - Apresentação do problema;

- $\quad$ Etapa 02 - Criação de ideias;

- $\quad$ Etapa 03 - Revisão das ideias;

- $\quad$ Etapa 04 - Seleção de ideias;

- $\quad$ Etapa 05 - Priorização de ideias.

Segundo Roldan et al., 2009, o Brainstorming é uma ferramenta da qualidade de fácil aplicação, bastante utilizada nas organizações e consiste em estimular e gerar ideias para encontrar a solução de determinados problemas. Cada participante da reunião Brainstorming de tem livre expressão para expor sua ideia e não deve ser feita nenhuma crítica. Todas as ideias discutidas na reunião deverão ser anotadas, ordenadas a fim de serem analisadas posteriormente por meio de outras ferramentas.

\subsubsection{Fluxograma.}

Segundo Megna (2016), o fluxograma é uma ferramenta da qualidade que permite representar as atividades de processo por meio de símbolos, ter uma visão geral da sequência das atividades, e como se relacionam umas com as outras.

Segundo Mello (2008), existem várias vantagens na utilização do fluxograma, pois permite verificar a forma que cada componente se relaciona em um sistema, facilita a análise das atividades que não agregam valor, pode ser utilizado para encontrar deficiências no processo e mostra os passos necessários para a realização das atividades.

Existem vários formatos de fluxogramas, sendo que os mais utilizados são fluxograma do tipo horizontal e vertical, e nos dois casos são desenhados com formas geométricas contendo uma breve descrição do processo, juntamente com setas e linhas mostrando a sequência de atividades (MARTINS, 2012). Na Figura 2 é possível visualizar um exemplo de fluxograma do tipo horizontal. 


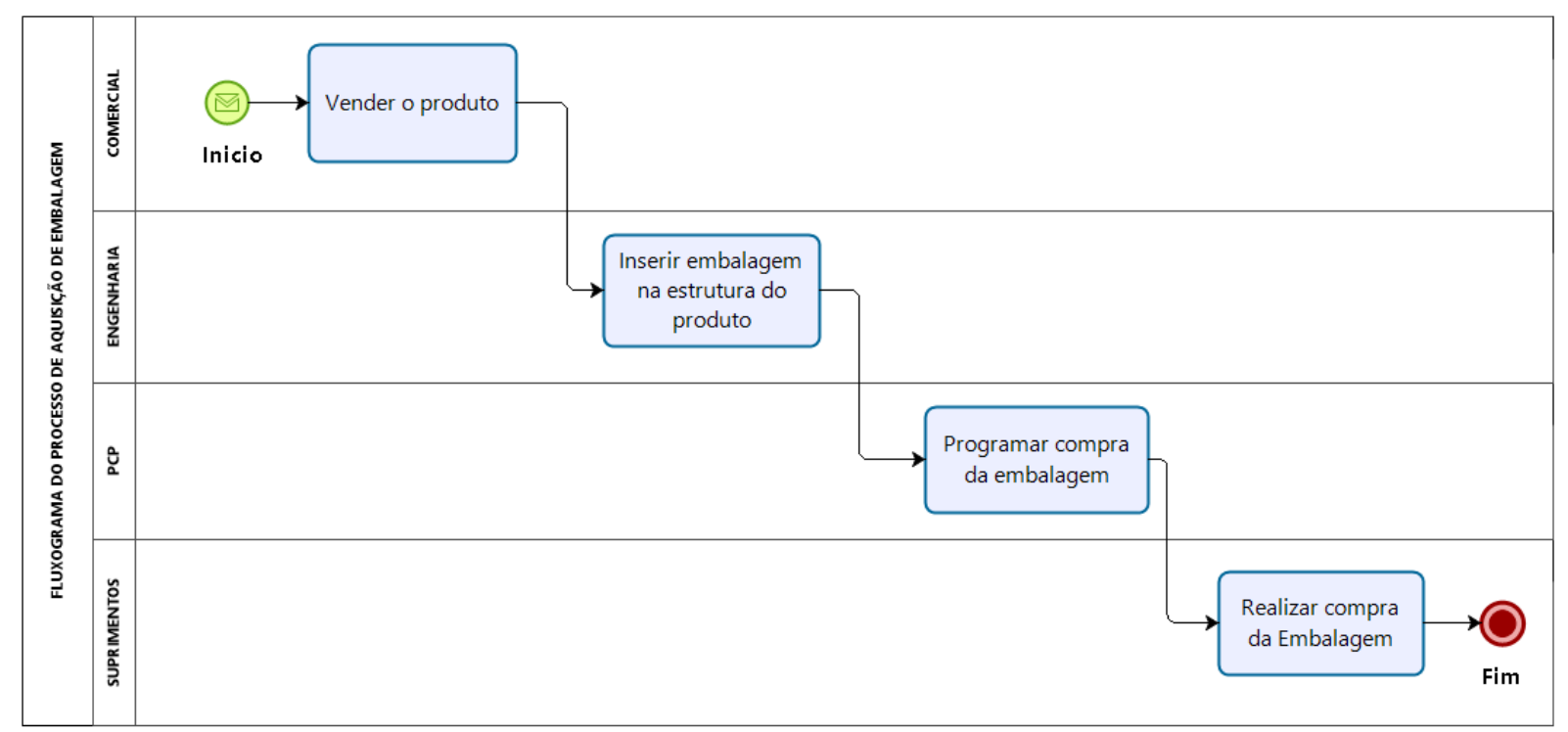

Figura 2 - Exemplo de um fluxograma tipo horizontal

Fonte: Elaborado pelo autor (2019).

\subsubsection{Matriz GUT}

Segundo Bastos (2014) a ferramenta da qualidade Matriz GUT foi criada por Kepner e Tregoe, ambos especialistas na solução de problemas organizacionais. O objetivo desta ferramenta é orientar na tomada de decisões mais complexas, principalmente na definição das ações prioritárias para a resolução de determinado problema. De acordo com Hékis et al. (2013, p.23) essa ferramenta responde racionalmente às seguintes perguntas, "qual a primeira ação que deve ser feita?", e, "por onde deve-se começar a implementar as ações?". Primeiramente qualifica-se o problema depois deverá ser atribuída uma nota correspondente conforme estabelecida na matriz, levando em consideração a gravidade, urgência e tendência em resolver o mesmo. Daychoum (2011) define a matriz GUT como uma técnica utilizada para priorizar os problemas e tratá-los. Para tanto, é muito importante considerar os fatores gravidade, urgência e tendência, atribuindo uma pontuação numa escala de 1(um) a 5 (cinco), em que resultados de valores mais expressivos terão prioridades para serem implementadas as ações para a solução do problema. A figura 3 mostra um exemplo da aplicação da matriz GUT.

\begin{tabular}{|c|c|c|c|c|c|}
\hline \multicolumn{6}{|c|}{ MATRIZ GUT } \\
\hline & G & $\mathbf{u}$ & $\mathbf{T}$ & & \\
\hline PONTOS & $\begin{array}{l}\text { GRAVIDADE } \\
\text { Consequência se } \\
\text { nada for feito }\end{array}$ & $\begin{array}{c}\text { URGÊNCIA } \\
\text { Prazo para tomada } \\
\text { de decisão. }\end{array}$ & $\begin{array}{c}\text { TENDÊNCIA } \\
\text { Proporção do } \\
\text { problema no Futuro. }\end{array}$ & $\mathbf{G} \times \mathbf{U} \times \mathbf{T}$ & PRIORIDADE \\
\hline 5 & Extremamente grave & Ação imediata & $\begin{array}{l}\text { Vai piorar } \\
\text { rapidamente }\end{array}$ & $5 \times 5 \times 5$ & 125 \\
\hline 4 & Muito grave & Com alguma urgência & $\begin{array}{c}\text { Vai piorar em pouco } \\
\text { tempo }\end{array}$ & $4 \times 4 \times 4$ & 64 \\
\hline 3 & Grave & O mais cedo possivel & $\begin{array}{c}\text { Vai piorar em médio } \\
\text { prazo }\end{array}$ & $3 \times 3 \times 3$ & 27 \\
\hline 2 & Pouca gravidade & $\begin{array}{l}\text { Pode esperar um } \\
\text { pouco }\end{array}$ & $\begin{array}{l}\text { Vai piorar em longo } \\
\text { prazo }\end{array}$ & $2 \times 2 \times 2$ & 8 \\
\hline 1 & Sem gravidade & Não tem pressa & Não vai piorar & $1 \times 1 \times 1$ & 1 \\
\hline
\end{tabular}

Figura 3 - Exemplo de uma matriz GUT

Fonte: Elaborado pelo autor (2019). 


\subsection{4 "Os 5 Por quês"}

Segundo Aguiar (2014) esta técnica consiste em fazer sucessivas perguntas até encontrar as causas raízes de um determinado problema, sendo que o primeiro dos por quês deve ser estruturado construído utilizando o próprio problema, e deve obter a resposta por quê o problema está ocorrendo. O segundo por quê deve ser elaborado utilizando a resposta do primeiro por quê e assim sucessivamente, até que seja encontrada a causa raiz do problema. A princípio pode aparentar ser fácil a utilização desta ferramenta, porém para que se tenha um bom fundamento na análise, requer um julgamento lógico do líder e toda a equipe envolvida. Na figura 4 pode-se observar as orientações aplicadas na utilização da ferramenta 5 Por quês.

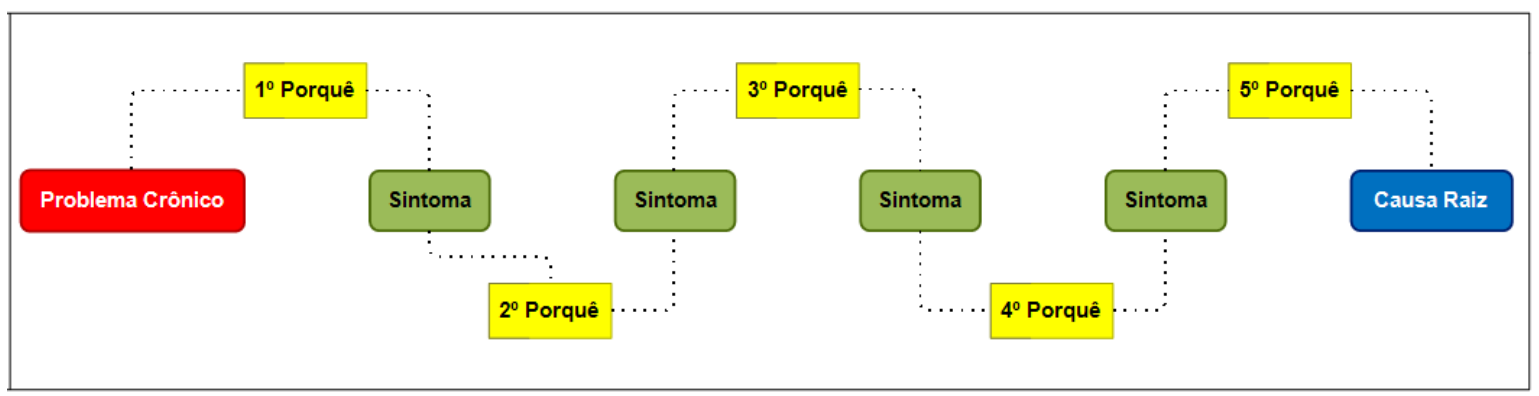

Figura 4 - Orientação para aplicação dos 5 Por quês.

Fonte: Elaborado pelo autor (2019).

Uma vez identificadas às causas-raiz, pode ser elaborado um plano de ação de forma estruturado por meio da ferramenta $5 \mathrm{~W} 2 \mathrm{H}$ e então obter um planejamento para as ações propostas.

\subsubsection{W2H}

De acordo com Silveira et al. (2016), a ferramenta 5W2H consiste em um checklist em que são listadas e planejadas as ações para resolução de um determinado problema, constando prazo definindo e responsabilidades de quem irá executá-las. Segundo Maiczuk e Júnior (2013), a técnica 5W2H é também aplicada para diagnosticar um problema, analisar recursos, determinar métodos, definição de prazos e melhorar o entendimento das responsabilidades. A figura 5 mostra os passos que deverão ser seguidos quando se deseja aplicar a ferramenta $5 \mathrm{~W} 2 \mathrm{H}$. 


\begin{tabular}{|c|c|c|c|c|}
\hline & \multicolumn{2}{|c|}{ Passos } & Conteúdo das respostas & Exemplos de perguntas \\
\hline \multirow{14}{*}{$5 W$} & \multirow{4}{*}{ What? } & \multirow{4}{*}{ O que? } & \multirow{4}{*}{ Ações necessárias ao tema analisado } & O que deve ser ou está sendo feito? \\
\hline & & & & Quais os insumos do problema/processo? \\
\hline & & & & O que se pretende extrair do problema/processo? \\
\hline & & & & Quais os métodos, materiais e tecnologias que devem ser \\
\hline & \multirow{3}{*}{ Who? } & \multirow{3}{*}{ Quem? } & \multirow{3}{*}{ Responsabilidade pelas ações } & Quem são os agentes envolvidos? \\
\hline & & & & Quem conhece melhor o processo? \\
\hline & & & & Quais pessoas devem executar o plano de ação? \\
\hline & \multirow{2}{*}{ Where? } & \multirow{2}{*}{ Onde? } & \multirow{2}{*}{ Locais influenciados pelas ações } & Onde ocorre/ocorreu o problema? \\
\hline & & & & Onde é preciso atuar para corrigir o problema? \\
\hline & \multirow{2}{*}{ When? } & \multirow{2}{*}{ Quando? } & \multirow{2}{*}{ Definir prazos } & Quando começar e terminar? \\
\hline & & & & Quando deverão ser executadas cada etapa do plano? \\
\hline & \multirow{3}{*}{ Why? } & \multirow{3}{*}{ Por quê? } & \multirow{3}{*}{ Justificativa das ações } & Por que ocorre este problema? \\
\hline & & & & Por que executar desta forma? \\
\hline & & & & Por que atuar neste problema? \\
\hline \multirow{6}{*}{$2 \mathrm{H}$} & \multirow{3}{*}{ How? } & \multirow{3}{*}{ Como? } & \multirow{3}{*}{ Métodos a serem utilizados } & Como será executado o plano? \\
\hline & & & & Como registrar as informações necessárias? \\
\hline & & & & Como definir as etapas do processo? \\
\hline & \multirow{3}{*}{ How much? } & \multirow{3}{*}{ Quanto custa? } & \multirow{3}{*}{ Definir orçamento } & Quanto será o custo envolvido? \\
\hline & & & & Quanto custará os recursos envolvidos? \\
\hline & & & & Quanto custa corrigir o problema? \\
\hline
\end{tabular}

Figura 5 - Orientações para elaboração um plano de ação - 5W2H

Fonte: Adaptado pelo autor (2019).

\subsection{Padronização}

Segundo Moura (1997) a padronização é uma das razões mais importantes para que exista uma interação eficiente entre a embalagem e a movimentação de materiais, com isso é possível controlar a variabilidade das embalagens. Quando se possui um número menor de tipos de embalagens é possível à criação de métodos e procedimentos para transporte e armazenagem, mitigando assim os possíveis erros humanos.

Com a padronização pode-se também diminuir os investimentos em diferentes tipos de equipamentos, além de que com o aumento do volume comprado dos fornecedores de apenas um tipo de material em alto volume, aumenta o poder de barganha na negociação da compra deste único item e diminui-se o estoque a ser mantido, já que os materiais são padronizados. Com a redução dos custos em geral é possível direcionar esse capital para novos investimentos ou subsidiar uma operação a fim de gerar vantagem competitiva para a empresa. Como ponto negativo da padronização, tem-se que se algum problema ocorrer no fornecimento de uma matéria-prima, por exemplo, para essa embalagem, nenhum item poderá ser produzido, o que significa uma parada geral na linha de produção de determinados produtos.

\section{Procedimentos Metodológicos.}

\subsection{Aplicações do método pesquisa-ação.}

Este estudo foi desenvolvido utilizando à abordagem metodológica a pesquisa-ação, que segundo Thiollent (2007), é um tipo de pesquisa empírica concebida e realizada em associação com uma ação ou resolução de um problema, no qual os pesquisadores e os participantes representativos da situação ou do problema estão envolvidos de modo cooperativo ou participativo. 


\subsection{Utilização de Ferramentas da Qualidade.}

Apesar de que existem diversas ferramentas da qualidade disponíveis para aplicação na resolução de problemas, neste trabalho foi necessário utilizar apenas as seguintes ferramentas: Brainstorming, Matriz GUT, os 5Porqês, 5W2H e o Fluxograma, visto o escopo do problema a ser resolvido.

\subsection{Caracterizações da empresa.}

O trabalho foi desenvolvido em uma empresa fabricante de medidores de energia elétrica, a qual faz parte de um grupo de empresa que possui mais de 20 anos de experiência no desenvolvimento e fabricação de medidores e que figura entre uma das líderes mundiais em medição de energia, vendendo mais de 16 milhões de medidores por ano e soluções AMI (Infraestrutura Avançada de Medição) possuindo fabricação, vendas, suporte e escritórios administrativos para apoiar as necessidades de seus clientes em todo o mundo, tendo como resultado alcançado no projeto, à padronização da utilização de embalagens por meio das ferramentas da qualidade.

\subsection{Embalagens e Papelão Ondulado.}

Segundo Rocha (2015), as embalagens possuem um papel importante na proteção, no armazenamento, na movimentação e no manuseio, seja no processo produtivo ou na própria logística, contribuindo assim para reduzir tempo de realização de tarefas e os custos. O mesmo autor destaca ainda, a relevância em se obter embalagens mais padronizadas a fim de se evitar erros no manuseio e também reduzir o número de itens a serem controlados em estoque, fazendo com que o maior número de produtos utilize a mesma embalagem (ROCHA, 2015).

Segundo Gurguel (2007), a embalagem vai depender do tipo de produto que será armazenado nela, do valor dos materiais contidos na mesma, mercado no qual empresas estão inseridas, as restrições de clientes e os órgãos governamentais. O mesmo autor ainda acrescenta, que as embalagens, principalmente as do tipo industriais, devem ser ajustadas de forma que possuam um bom nível de ocupação de sua área interna, sem deixar espaços vazios, acrescenta a importância da preservação do produto durante o processo produtivo para que o mesmo não seja danificado ou avariado ao ser transportado. Por esse motivo todos os detalhes devem ser analisados cuidadosamente durante o desenvolvimento das embalagens.

Antigamente utilizava-se embalagem somente para proteção de seus produtos, porém, atualmente é comum empresas investirem em embalagens mais requintadas para que por meio delas possam se diferenciar dos concorrentes.

Carvalho (2008) considera três tipos de embalagens industriais: primária, coletiva e transporte. A embalagem do tipo primária possui contato direto com o produto, a coletiva engloba diversas embalagens primárias, já a de transporte é utilizada para movimentação de produtos fora das dependências da empresa e contém várias embalagens coletivas.

Segundo Vidal (2012), o papelão ondulado é fabricado a partir de fibras longas provenientes de fibras virgens ou reciclado de madeira Pinus. É considerada uma das principais matérias-primas utilizada para fabricação de embalagens devido a sua estrutura, garantindo principalmente proteção interna, manuseio e capacidade de estocagem nas mais variadas condições em que os produtos estão expostos (VIDAL, 2012).

A norma NBR 5985:2008 classifica o papelão ondulado da seguinte forma: 
- Face simples: esta estrutura é formada por um miolo (elemento ondulado) colado a uma capa (elemento plano);

- Parede simples: estrutura formada por um miolo colado, em ambos os lados, à capas;

- Parede dupla: estrutura formada por três capas coladas a dois miolos intercaladamente;

- Parede tripla: estrutura formada por quatro capas coladas em três miolos intercaladamente;

- Parede múltipla: estrutura formada por cinco ou mais capas coladas a quatro ou mais miolos intercaladamente.

Para que se tenha um melhor entendimento sobre a classificação do papelão ondulado, a figura 6 exemplifica por meio de imagens, os tipos de parede e elementos do papelão ondulado.

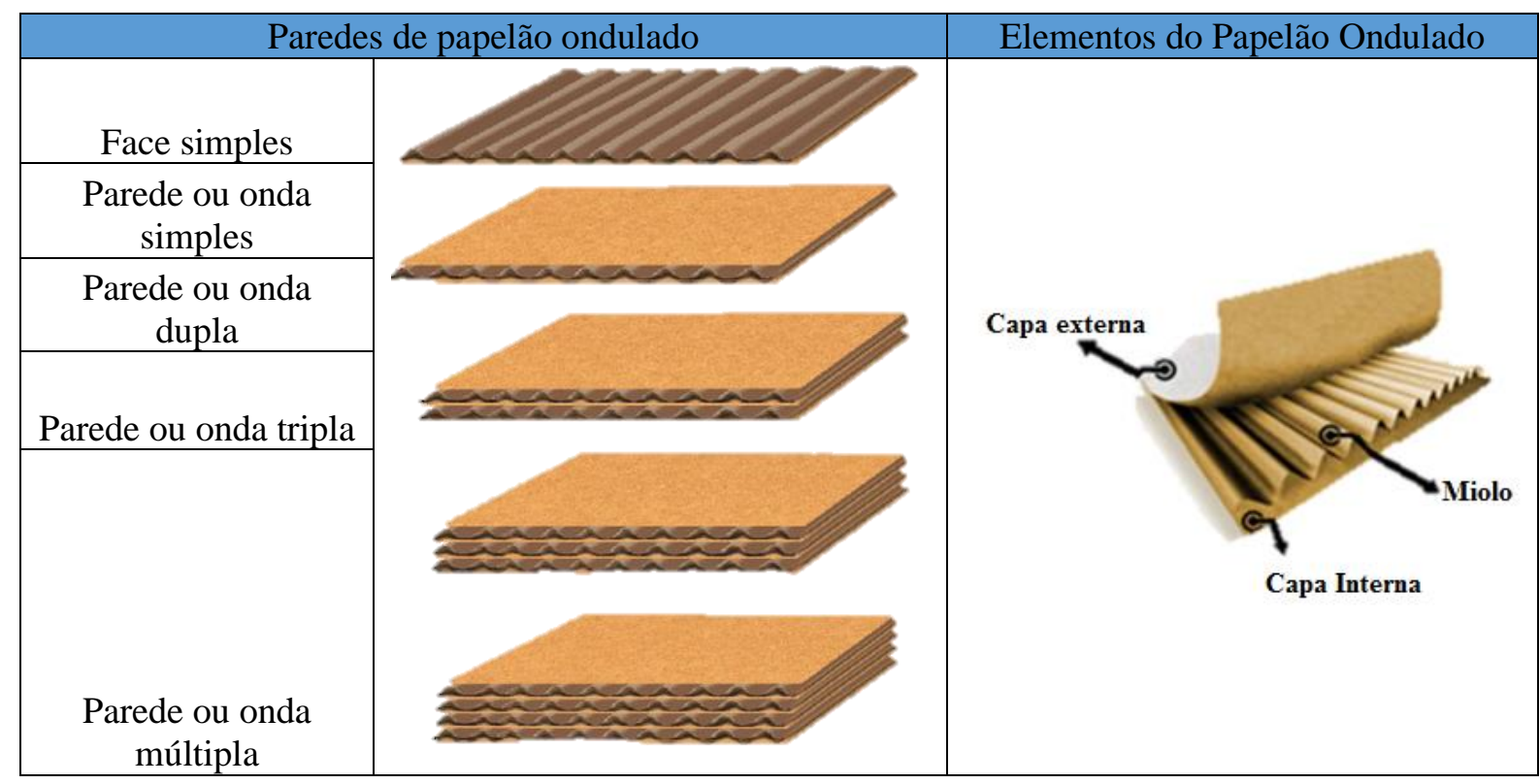

Figura 6 - Tipos de papelão Ondulado

Fonte: Elaborado pelo autor (2019).

Normalmente, a capa interna é a que possui uma maior resistência quando a embalagem está preenchida com o produto e sofre um esforço de compressão, a parede interna tem tendência em fazer uma compressão e a parte externa sofre uma tração (PEREIRA, 2016).

Além do conhecimento sobre a classificação do papelão ondulado, existem outras características e fatores que são únicos quando se fala em caixa de papelão e que devem ser levados em consideração, como: design, qualidade do papel e tipo de onda. A figura 7 mostra as especificações do tipo de onda e suas respectivas espessuras.

\begin{tabular}{|c|c|}
\hline Tipo & Espessuras \\
\hline Onda-F (Micro Ondulado) & $0.8 \mathrm{~mm}$ \\
\hline Onda-E (Micro Ondulado) & $1.2 \mathrm{~mm}$ \\
\hline Onda-B (Onda Baixa) & $2.4 \mathrm{~mm}$ \\
\hline Onda-C (Onda Média) & $3.6 \mathrm{~mm}$ \\
\hline Onda-A (Onda Alta) & $4.8 \mathrm{~mm}$ \\
\hline
\end{tabular}

Figura 7 - Espessuras dos tipos de ondas do papelão ondulado

Fonte: https://papelaoondulado.wordpress.com/tag/tipos-de-papelao/. 


\subsection{Etapas da realização do trabalho}

Para orientação deste trabalho, foi elaborado um diagrama conforme ilustrado na figura 8 , mostrando todas as etapas do projeto de melhoria, as quais serão explodidas no tópico da apresentação e discussão dos resultados, informando o passo a passo de como foram executadas.

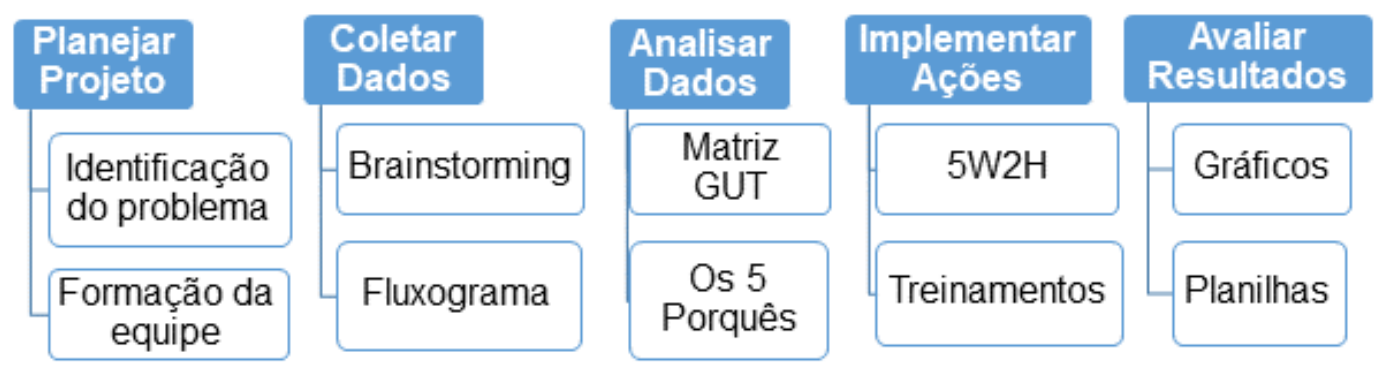

Figura 8 - Etapas da realização do trabalho Fonte: Elaborado pelo autor, 2019.

Na primeira etapa, identificou-se o problema a ser resolvido diante de uma solicitação da diretoria de operações. Formou-se uma equipe multidisciplinar dentro da organização estudada, composta por colaboradores das áreas de Engenharia de Produto, Engenharia de Processo, Qualidade, Comercial, Suprimentos, PCP, Produção, Almoxarifado e Controladoria. Nesta etapa houve o entendimento do problema e o mesmo foi discutido entre os membros da equipe, visando tratar da importância da realização do projeto para estratégia da empresa estudada.

Na segunda etapa, iniciou-se com um brainstorming com a participação de todos os membros da equipe do projeto para discutir e identificar as possíveis causas do problema analisado. Foi mapeado através de um fluxograma todo o processo que envolve o desenvolvimento de embalagem e realizou-se também entrevistas e questionários com colaboradores da organização estudada, a fim de se obter mais informações sobre o problema analisado.

$\mathrm{Na}$ terceira etapa, a partir das informações levantadas na segunda etapa, buscou-se analisar e priorizar as possíveis causas do problema utilizando a ferramenta Matriz GUT e para solucionar o problema de forma definitiva, utilizou-se a técnica dos 5 Porquês para identificar as causas raízes.

Na quarta etapa, após a identificação das principais causas do problema, foi definido um plano de ação com o uso da ferramenta $5 \mathrm{~W} 2 \mathrm{H}$, onde foram listadas e planejadas as principais ações para resolução do problema analisado, constando prazos e responsáveis que iriam executá-las.

$\mathrm{Na}$ quinta etapa, depois da aplicação das ações propostas, avaliou-se de forma comparativa os dados de antes e depois da implementação do projeto, por meio de gráficos e planilhas com dados coletados na segunda etapa.

\section{Apresentação de Resultados.}

Nesta seção serão apresentadas as principais atividades desenvolvidas em cada etapa do projeto estudado, tal como os dados e as informações utilizadas para alcançar os resultados propostos. 


\subsection{Planejar Projeto}

$\mathrm{Na}$ empresa objeto deste trabalho, contava-se com uma grande variedade de itens de embalagem, incluindo caixas coletivas, caixas individuais e conjuntos de divisórias. Isso estava ocasionando uma série de problemas, principalmente no gerenciamento da armazenagem, no custo da aquisição, dificuldade de manuseio no processo produtivo e dead stock no almoxarifado.

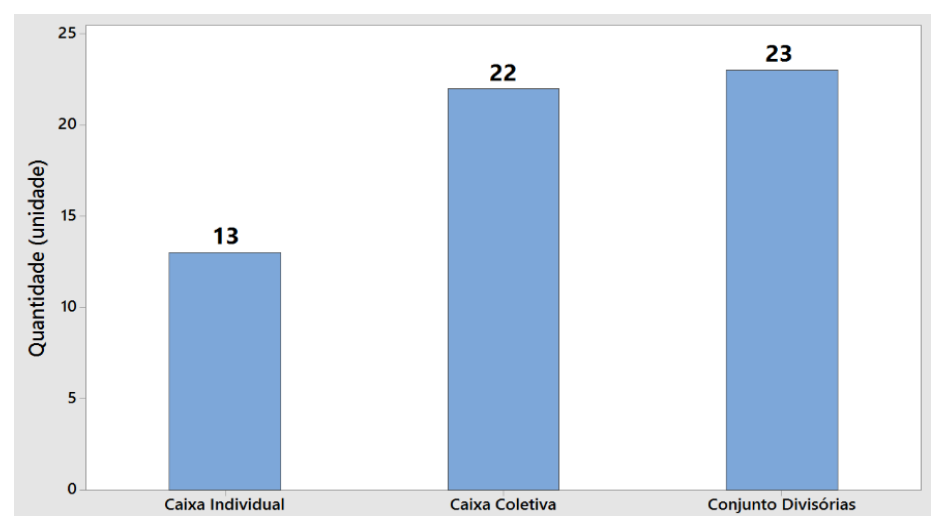

Figura 9 - Quantidade de itens de embalagens existentes.

Fonte: Elaborado pelo autor (2019).

Pode-se observar na figura 9 as quantidades de itens existentes, no caso, 13 modelos de caixas individuais, 22 modelos de caixas coletivas e 23 modelos conjuntos de divisórias.

Na figura 10 é possível visualizar através de imagens os três tipos de embalagens estudadas neste trabalho, as quais serão detalhadas nas seções posteriores.

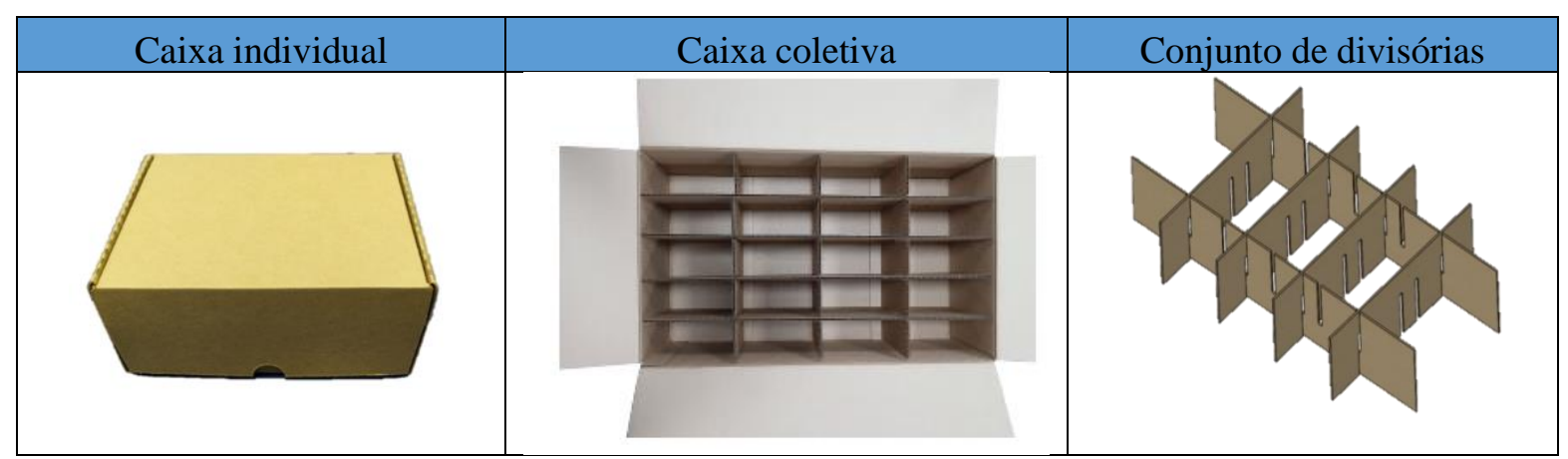

Figura 10 - Exemplo de tipos de itens de embalagens.

Fonte: Elaborado pelo autor (2019).

A seguir será detalhada a aplicação de cada tipo de embalagens estudado.

a) Caixa Individual: embalagem para armazenar um único produto dentro de uma caixa coletiva, considera-se como uma embalagem primária;

b) Caixa coletiva: utilizada para armazenar vários produtos por meio de uma embalagem primária, no caso, caixas individuais ou conjunto de divisórias;

c) Conjunto de Divisórias: tipo de embalagem utilizado para separar determinados produtos dentro da caixa coletiva.

Diante do problema em questão, foi formada uma equipe multidisciplinar, conforme mostra a figura 11, composta por profissionais de diversas áreas, para que juntos pudessem discutir e identificar as possíveis causas que contribuem para a ocorrência do problema e encontrar uma solução. 


\begin{tabular}{|l|l|c|}
\cline { 2 - 2 } \multicolumn{1}{c|}{} & \multicolumn{1}{c|}{ Função } & Setor \\
\hline \multirow{4}{*}{ Patrocinadores: } & Diretor de Operação & \multirow{2}{*}{ Diretoria } \\
\cline { 2 - 2 } & Diretor de Tecnologia & \multirow{2}{*}{ Engenharia } \\
\cline { 2 - 3 } & Analista de Engenharia & Processo \\
\hline \multirow{4}{*}{$\begin{array}{c}\text { Membros da } \\
\text { equipe: }\end{array}$} & Desenhista Projetista & Qualidade \\
\cline { 2 - 3 } & Analista de Processo & PCP \\
\cline { 2 - 3 } & Analista da Qualidade & Suprimentos \\
\cline { 2 - 3 } & Programador de PCP & Comercial \\
\cline { 2 - 3 } & Analista de Compra & Produção \\
\cline { 2 - 3 } & Analista Comercial & Almoxarifado \\
\cline { 2 - 3 } & Operador de Embalagem & Controladoria \\
\cline { 2 - 3 } & Encarregado de Almoxarifado & \\
\cline { 2 - 3 } & Coordenador de custos & \\
\hline
\end{tabular}

Figura 11 - Equipe do projeto

Fonte: Elaborado pelo autor (2019).

\subsection{Coletar dados.}

Esta etapa iniciou-se a partir de uma reunião com a equipe por intermédio de um brainstorming, em que foram discutidas, identificadas e listadas as possíveis causas que mais poderiam contribuir para a ocorrência do problema, conforme mostra a figura 12.

\begin{tabular}{|c|l|}
\hline \multicolumn{2}{|c|}{ Problema: Grande variedade de itens de embalagens } \\
\hline Item & \multicolumn{1}{c|}{ Possíveis causas do problema } \\
\hline 01 & Existe uma embalagem específica para cada tipo de produto \\
\hline & \\
\hline 02 & Os produtos não possuem dimensões externas padronizadas \\
\hline 03 & Existência de especificação customizada de clientes \\
\hline 04 & Projeto de produtos obsoletos, sem demanda comercial \\
\hline 05 & Postergação de pedido de venda de produto \\
\hline 06 & Plano comercial de venda não concretizado \\
\hline 07 & Imprecisão na concepção do projeto do produto \\
\hline 08 & Erro na elaboração do desenho técnico da embalagem \\
\hline 09 & Matéria-prima da embalagem mal especificada \\
\hline 10 & Falha na comunicação no processo de aquisição de embalagem \\
\hline
\end{tabular}

Figura 12 - Reunião do Brainstorming

Fonte: Elaborado pelo autor (2019).

Posteriormente essas possíveis causas foram transportadas para a matriz GUT, na qual foram discutidas novamente e analisadas por toda equipe, atribuídas notas levando em conta a gravidade, urgência e tendência de cada problema. 
Os membros da equipe fizeram uma visita no almoxarifado da fábrica, conforme mostra a figura 13, com o propósito de obter dados sobre o problema, entrevistando pessoas para listar reclamações e sugestões que na visão delas poderiam resolver ou amenizar o problema.
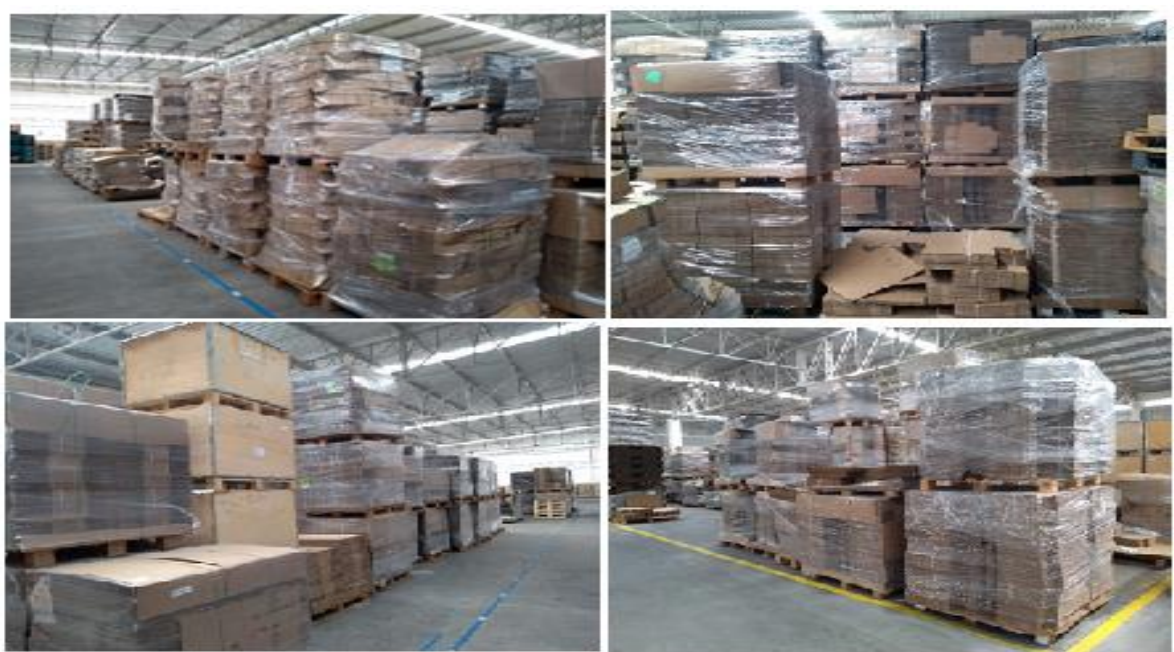

Figura 13 - Visita da equipe no almoxarifado.

Fonte: Elaborado pelo autor (2019).

A fim de obter mais dados sobre o problema analisado, foi mapeado o macroprocesso do desenvolvimento de embalagens por meio de um fluxograma (figura 14), o qual permitiu compreender, identificar as áreas envolvidas e o papel de cada participante, com isso foi possível saber onde realmente as possíveis causas levantadas acontecem de fato.

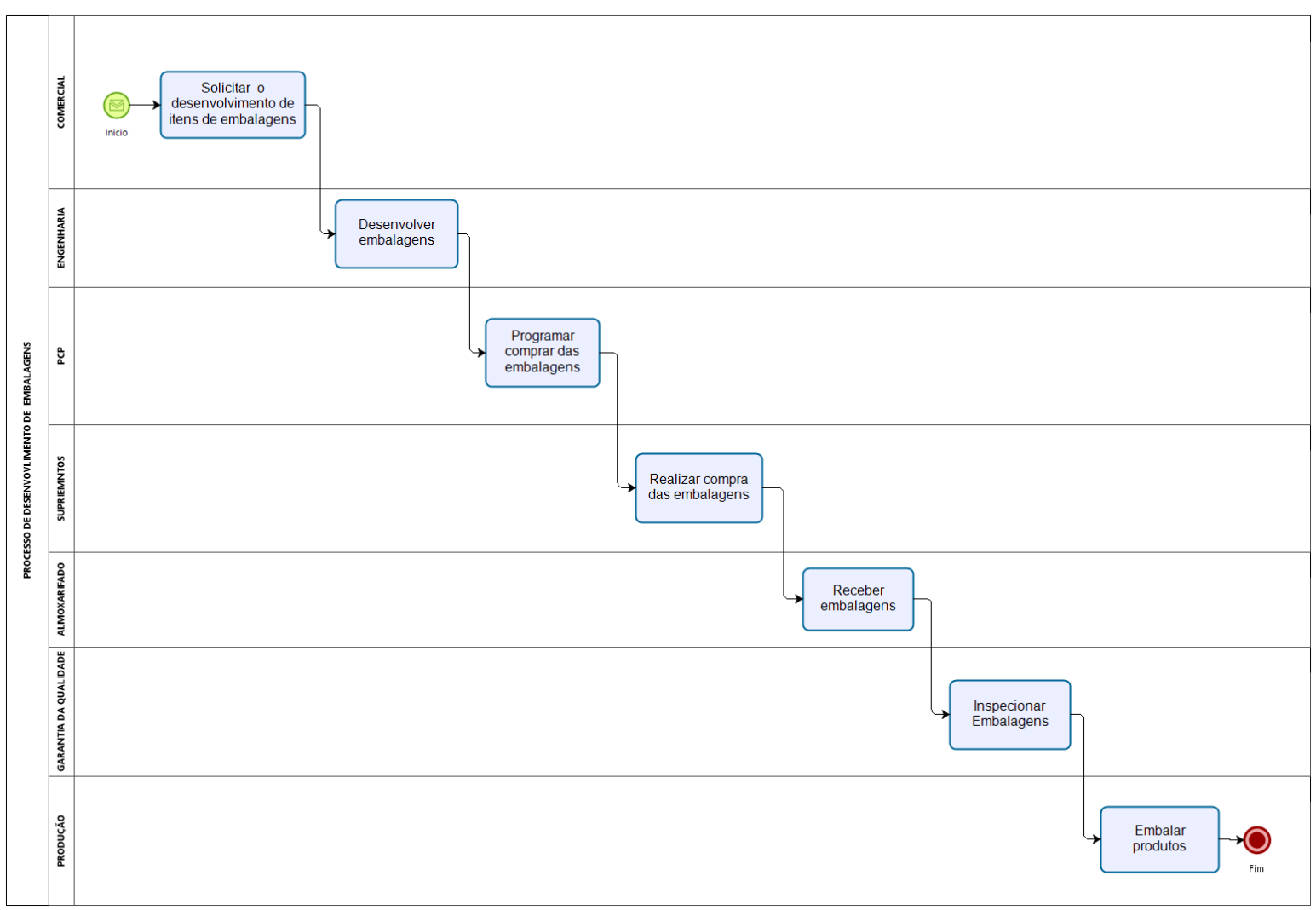

Figura 14 - Fluxograma do macroprocesso do desenvolvimento de embalagem. Fonte: Elaborado pelo autor, 2019. 
A figura 14 detalha o fluxo do processo de desenvolvimento de embalagem, conforme etapas descritas a seguir:

$1^{a}$ Etapa: o processo é iniciado pela área comercial, solicitando o desenvolvimento dos itens de embalagem sempre que é homologado um novo produto;

$2^{a}$ Etapa: a engenharia desenvolve a embalagem junto aos fornecedores conforme especificação enviada pela área comercial;

$3^{\text {a }}$ Etapa: a área de PCP faz a programação da compra conforme demanda comercial;

$4^{\text {a }}$ Etapa: o setor de suprimentos realiza a compra conforme programação de compra de materiais enviada pelo PCP;

$5^{\mathbf{a}}$ Etapa: a área da qualidade inspeciona as embalagens adquiridas dos fornecedores e libera para a produção, caso esteja conforme especificação determinada nos desenhos técnicos.

$6^{a}$ Etapa: a área da produção embala os produtos nas embalagens e faz a expedição para os clientes.

\subsection{Analisar dados.}

Após coletar os dados por meio do brainstorming, fluxograma do processo e entrevistas com pessoas envolvidas na problemática, as possíveis causas foram analisadas, interpretadas e detalhadas com auxílio da matriz GUT, conforme detalhado na figura 15, a fim de priorizar as ações que mais influenciavam na ocorrência do problema.

\begin{tabular}{|c|c|c|c|c|c|}
\hline \multirow{2}{*}{. } & \multirow{2}{*}{ Possiveis Causas do Problema } & \multicolumn{4}{|c|}{ Matriz GUT } \\
\hline & & GRAVIDADE & URGÊNCIA & TENDÊNCIA & PRIORIDADE \\
\hline 1 & Existe uma embalagem especifica para cada tipo de produto & 5 & 5 & 5 & 125 \\
\hline 2 & Os produtos não possuem dimensões externas padronizadas & 5 & 5 & 5 & 125 \\
\hline 3 & Existência de especificação customizada de clientes & 5 & 5 & 5 & 125 \\
\hline 4 & Projeto de produtos obsoletos, sem demanda comercial & 3 & 3 & 4 & 36 \\
\hline 5 & Postergação de pedido de venda de produto & 3 & 2 & 3 & 18 \\
\hline 6 & Plano comercial de venda não concretizado & 2 & 3 & 3 & 18 \\
\hline 7 & Imprecisão na concepção do projeto do produto & 2 & 3 & 3 & 18 \\
\hline 8 & Erro na elaboração do desenho técnico da embalagem & 2 & 4 & 2 & 16 \\
\hline 9 & Matéria-prima da embalagem mal especificada & 2 & 3 & 3 & 18 \\
\hline \multirow[t]{2}{*}{10} & Falha na comunicação no processo de aquisição de embalagem & 2 & 2 & 2 & 8 \\
\hline & & \multicolumn{4}{|c|}{$\mathbf{G} \times \mathbf{U} \times \mathbf{T}=\mathbf{P}$} \\
\hline
\end{tabular}

Figura 15 - Matriz GUT.

Fonte: Elaborado pelo autor (2019).

De acordo com análise da equipe por meio da utilização da matriz GUT, as principais causas que contribuem para a grande variedade de itens de embalagem na empresa objeto deste estudo, foram as seguintes:

a) Existe uma embalagem específica para cada tipo de produto;

b) Os produtos não possuem dimensões externas padronizadas;

c) Existência de especificação customizada de clientes.

Essas causas foram analisadas e discutidas de forma mais criteriosas pela técnica dos 5 Porquês, conforme mostra a figura 16, objetivando verificar as causas raízes e assim encontrar uma solução que realmente eliminasse o problema de forma definitiva. 


\begin{tabular}{|c|l|}
\hline Problema: & \multicolumn{1}{|c|}{ Grande variedade de itens de embalagens na empresa } \\
\hline $\mathbf{1}^{\mathbf{a}}$ Causa & Existe uma embalagem específica para cada tipo de produto \\
\hline Porque 1 & A cada novo produto, desenvolve-se uma nova embalagem. \\
\hline Porque 2 & A área comercial atende os requisitos no contrato de clientes \\
\hline Porque 3 & $\begin{array}{l}\text { Não existe uma análise para saber se as embalagens atuais atendem os novos } \\
\text { produtos desenvolvidos. }\end{array}$ \\
\hline Porque 4 & $\begin{array}{l}\text { Falta um procedimento que determine que antes de iniciar o desenvolvimento de } \\
\text { novas embalagens, deverá analisar se as atuais atendem para os novos produtos. }\end{array}$ \\
\hline Porque 5 & $\begin{array}{l}\text { Não foi pensando pelas áreas envolvidas esta possibilidade de uso de embalagens } \\
\text { existentes para os novos produtos. }\end{array}$ \\
\hline Causa raiz & $\begin{array}{l}\text { Não existe análise da área responsável pelo desenvolvimento de embalagens, para } \\
\text { verificar se as embalagens atuais atendem aos novos produtos desenvolvidos. }\end{array}$ \\
\hline
\end{tabular}

\begin{tabular}{|c|l|}
\hline $\mathbf{2}^{\mathbf{a}}$ Causa & Os produtos não possuem dimensões externas padronizadas \\
\hline Porque 1 & Não existe padronização das dimensões externa dos produtos. \\
\hline Porque 2 & $\begin{array}{l}\text { Dependendo das características ou funcionalidades de cada produto, pode haver uma } \\
\text { variação nas dimensões externas. }\end{array}$ \\
\hline Porque 3 & Para atender diversas aplicações e necessidades dos clientes. \\
\hline Porque 4 & $\begin{array}{l}\text { Com intuito de a empresa ser um diferencial para seus clientes e com isso tornar } \\
\text { mais competitiva no mercado. }\end{array}$ \\
\hline Porque 5 & \\
\hline Causa raiz & O não atendimento às características e funcionalidades de determinados produtos. \\
\hline
\end{tabular}

\begin{tabular}{|c|l|}
\hline $\mathbf{3}^{\text {a }}$ Causa & Existência de especificação customizada de clientes \\
\hline Porque 1 & Existe especificação de embalagens customizada por clientes. \\
\hline Porque 2 & $\begin{array}{l}\text { Alguns clientes especificam no contrato de compra, o tipo de embalagens que seus } \\
\text { produtos deverão ser embalados. }\end{array}$ \\
\hline Porque 3 & $\begin{array}{l}\text { Para que esses clientes possam atender as normas internas de segurança em suas } \\
\text { organizações. }\end{array}$ \\
\hline Porque 4 & $\begin{array}{l}\text { Os colaboradores não podem pegar caixas de medidores com peso bruto superior a } \\
10 \mathrm{~kg} \text {, por exemplo. }\end{array}$ \\
\hline Porque 5 & \multicolumn{1}{|c|}{ Atender as normas de segurança adotadas por alguns clientes. } \\
\hline Causa raiz & \multicolumn{1}{|c|}{} \\
\hline
\end{tabular}
Figura 16 - Ferramenta 5 Porquês.

Fonte: Elaborada pelo autor (2019).

A partir das causas raízes identificadas por meio da ferramenta dos 5 porquês, foi discutido e definido pela equipe do projeto que apenas uma única ação poderia resolver o problema apresentado neste trabalho. No caso, seria o desenvolvimento de novos itens de embalagens com a implementação de um projeto de melhoria, objetivando a padronização da utilização das mesmas nos produtos.

\subsection{Implementar ações.}

Após a decisão de desenvolver um projeto de melhoria visando à padronização das embalagens, foi definido um plano de ação visando buscar uma solução para resolver o problema citado neste trabalho. Utilizou-se a ferramenta $5 \mathrm{~W} 2 \mathrm{H}$ na qual foram relatadas as principais atividades que deveriam ser feitas, informando datas e os responsáveis pelas implementações, conforme observado a seguir na figura 17 . 


\begin{tabular}{|c|c|c|c|c|c|c|c|c|}
\hline Açöes & O que? & Quem? & Quando? & Onde? & Por que? & Como? & Quanto? & Status \\
\hline 1 & $\begin{array}{c}\text { Fazer parceria com fornecedor } \\
\text { de embalagem }\end{array}$ & $\begin{array}{l}\text { Analista de } \\
\text { Compra }\end{array}$ & $25 / 01 / 2019$ & Suprimentos & $\begin{array}{l}\text { Desenvolver juntamente com um fornecedor um novo projeto } \\
\text { de embalagem }\end{array}$ & $\begin{array}{c}\text { Discutindo e analisando uma forma de padronizar } \\
\text { as embalagens }\end{array}$ & Não aplicável & Concluido \\
\hline 2 & $\begin{array}{c}\text { Levantar todas as } \\
\text { caracteristicas das embalagens } \\
\text { atuais }\end{array}$ & $\begin{array}{l}\text { Desenhista } \\
\text { Projetista }\end{array}$ & $30 / 01 / 2019$ & Engenharia & $\begin{array}{l}\text { Avaliar a possibilidade de padronização das embalagens } \\
\text { para os produtos }\end{array}$ & $\begin{array}{l}\text { Verificando as dimensões externas das } \\
\text { embalagens especificadas nos desenhos técnicos. }\end{array}$ & Não aplicável & Concluido \\
\hline 3 & \begin{tabular}{|c|} 
Checar restriçõos e \\
especificações customizadas \\
dos clientes
\end{tabular} & $\begin{array}{l}\text { Analista de } \\
\text { Comercial }\end{array}$ & 11/02/2019 & Comercial & $\begin{array}{l}\text { Garantir que as restrições e especificações dos clientes } \\
\text { sejam consideradas no projeto }\end{array}$ & $\begin{array}{l}\text { Entrando em contato com os clientes e analisando } \\
\text { as especificações existentes }\end{array}$ & Não aplicável & Concluido \\
\hline 4 & $\begin{array}{c}\text { Desenvolver um novo projeto de } \\
\text { embalagem }\end{array}$ & $\begin{array}{l}\text { Analista de } \\
\text { Engenharia }\end{array}$ & 28/02/2019 & Engenharia & $\begin{array}{c}\text { Padronizar as embalagens utilizadas nos medidores de } \\
\text { energia elétrica }\end{array}$ & $\begin{array}{c}\text { Em parceria com um fornecedor especialista em } \\
\text { embalagem. }\end{array}$ & Não aplicável & Concluido \\
\hline 5 & Elaborar os desenhos técnicos & $\begin{array}{l}\text { Desenhista } \\
\text { Projetista }\end{array}$ & $29 / 03 / 2019$ & Engenharia & Especificar as dimensões e especificações das embalagens & Desenhando através de software $2 \mathrm{D}$ e $3 \mathrm{D}$ & Não aplicável & Concluido \\
\hline 6 & $\begin{array}{l}\text { Solicitar amostras de } \\
\text { embalagem }\end{array}$ & $\begin{array}{l}\text { Analista de } \\
\text { Compras }\end{array}$ & $30 / 04 / 2019$ & Suprimentos & Realizar as analise dimensional e funcional das embalagens & Solicitando através de e-mail & Não aplicável & Concluido \\
\hline 7 & $\begin{array}{c}\text { Realizar analise dimensional e } \\
\text { teste funcional }\end{array}$ & $\begin{array}{l}\text { Analista da } \\
\text { Qualidade }\end{array}$ & 25/05/2019 & Qualidade & $\begin{array}{l}\text { Verificar se as embalagens estão conforme especificação } \\
\text { nos desenhos técnicos }\end{array}$ & $\begin{array}{l}\text { Através de instrumentos de medição e testes } \\
\text { funcionais com produtos }\end{array}$ & Não aplicável & Concluido \\
\hline 8 & $\begin{array}{c}\text { Solicitar compra de } \\
\text { embalagens para realização do } \\
\text { lote piloto }\end{array}$ & $\begin{array}{l}\text { Analista de } \\
\text { Compras }\end{array}$ & 10/06/2019 & Suprimentos & $\begin{array}{l}\text { Avaliar as embalagens no processo produtivo através de um } \\
\text { lote piloto }\end{array}$ & $\begin{array}{l}\text { Conforme a quantidade informada pela equipe do } \\
\text { projeto de embalagem. }\end{array}$ & Não aplicável & Concluido \\
\hline 9 & $\begin{array}{l}\text { Elaborar instruç̃oes de } \\
\text { Engenharia }\end{array}$ & $\begin{array}{l}\text { Analista de } \\
\text { Processos }\end{array}$ & 20/06/2019 & Engenharia & $\begin{array}{l}\text { Instruir os operadores quanto manuseio das embalagens no } \\
\text { processo produtivo }\end{array}$ & $\begin{array}{l}\text { Criando um manual de embalagem informando as } \\
\text { combinações dos produtos dentro da embalagem }\end{array}$ & Não aplicável & Concluido \\
\hline 10 & $\begin{array}{l}\text { Realizar treinamento de } \\
\text { manuseio de embalagem. }\end{array}$ & $\begin{array}{l}\text { Analista de } \\
\text { Engenharia }\end{array}$ & |01/07/2019 & Engenharia & $\begin{array}{c}\begin{array}{c}\text { Treinar todos os colaboradores envolvidos no processo de } \\
\text { embalagem }\end{array}\end{array}$ & Através de Workshop & Não aplicável & Concluido \\
\hline 11 & $\begin{array}{l}\text { Realizar lote piloto das } \\
\text { embalagens }\end{array}$ & $\begin{array}{l}\text { Analista de } \\
\text { Engenharia }\end{array}$ & $30 / 07 / 2019$ & Engenharia & $\begin{array}{l}\text { Avaliar o comportamento das embalagens no processo } \\
\text { produtivo. }\end{array}$ & $\begin{array}{l}\text { Utilizando todas as embalagens do projeto no } \\
\text { processo produtivo. }\end{array}$ & Não aplicável & Concluido \\
\hline 12 & Fazer um plano de corte & $\begin{array}{l}\text { Programador de } \\
\text { PCP }\end{array}$ & 09/08/2019 & PCP & $\begin{array}{l}\text { Garantir que as novas embalagens só poderão ser utilizadas } \\
\text { após o consumo total das embalagens antigas }\end{array}$ & $\begin{array}{l}\text { Planejando via sistema a transição das } \\
\text { embalagens antigas para as novas embalagens }\end{array}$ & Não aplicável & Concluido \\
\hline 13 & Elaborar plano de controle & $\begin{array}{l}\text { Desenhista } \\
\text { Projetista }\end{array}$ & $30 / 08 / 2019$ & Engenharia & $\begin{array}{l}\text { Assegurar que qualquer desenvolvimento de novos produtos } \\
\text { não seja necessário desenvolver novos itens de embalagens }\end{array}$ & $\begin{array}{l}\text { Criando mecanismos para garantir que não sejam } \\
\text { criadas novas embalagens quando forem } \\
\text { desenvolvidos novos produtos }\end{array}$ & Não aplicável & Concluido \\
\hline 14 & $\begin{array}{l}\text { Apresentar os resultados do } \\
\text { projeto de embalagem }\end{array}$ & $\begin{array}{l}\text { Analista de } \\
\text { Engenharia }\end{array}$ & $31 / 08 / 2019$ & Engenharia & $\begin{array}{l}\text { Mostrar para as partes interessadas os ganhos obtidos com o } \\
\text { projeto de embalagem }\end{array}$ & $\begin{array}{l}\text { Apresentando os resultados através de uma } \\
\text { reunião com as partes interessadas }\end{array}$ & Não aplicável & Concluido \\
\hline
\end{tabular}

Figura 17 - Plano de ação utilizando a ferramenta 5W2H. 
De acordo com o plano de ação, a primeira atividade realizada foi fazer uma parceria com um fornecedor de embalagem da empresa, depois disso, realizou-se uma visita técnica por meio de um desenhista projetista e um analista de engenharia do produto na fábrica do fornecedor parceiro, para que juntos com os profissionais do mesmo pudessem dar início ao desenvolvimento do projeto. Durante este encontro que durou dois dias, foi possível realizar as seguintes ações:

- Discutir os resultados pretendidos com o projeto;

- Analisar os requisitos definidos no projeto;

- $\quad$ Definir a concepção das novas embalagens a serem desenvolvidas;

- $\quad$ Confeccionar amostras para realização de análise funcional e dimensional;

- Avaliar todas as combinações e arranjos das embalagens com produtos;

- Aprovar amostras preliminares das embalagens desenvolvidas

Essas ações realizadas durante a visita técnica contribuíram bastante para a agilidade da conclusão do projeto, pois, todas as ideias e dúvidas que fossem surgindo durante a visita técnica, eram ligeiramente esclarecidas e testadas juntamente com a equipe técnica do fornecedor. Além disso, foram levados para a fábrica do fornecedor de embalagem, todos os produtos que se pretendia desenvolver embalagens, a fim de facilitar a avaliação das possibilidades de padronização da utilização das embalagens e em seguida já saber os resultados das análises.

\subsection{Avaliação dos resultados.}

Após a aplicação das ações propostas no projeto de melhoria apresentado neste trabalho, destacaram as seguintes melhorias:

\subsubsection{Redução da variedade de itens de embalagens.}

O estudo analisado iniciou-se com o propósito de reduzir a variedade de itens de embalagens, visando à padronização da utilização nos produtos fabricados na empresa objeto deste trabalho. Diante deste problema, foi observada a oportunidade pela equipe do projeto, por meio da utilização de determinadas ferramentas da qualidade, que poderia encontrar-se uma solução para resolver este problema.

Pode-se observar na figura 18, o resultado e as melhorias obtidas referentes à principal proposta feita inicialmente com implementação do projeto. 


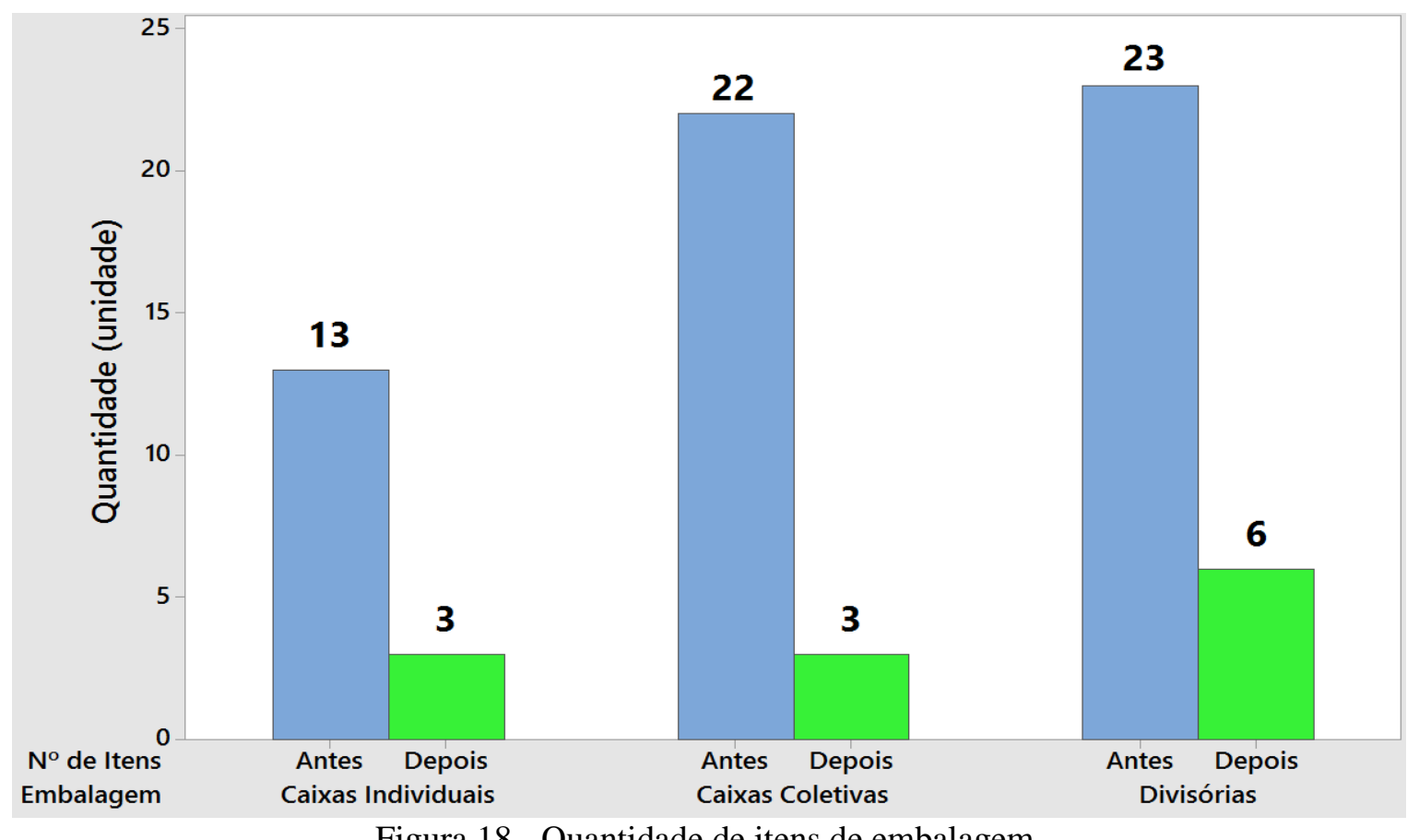

Figura 18 - Quantidade de itens de embalagem.

Fonte: Elaborada pelo autor (2019).

Pode-se observar na figura 18 as quantidades dos itens de embalagens antes e depois da implementação do projeto, sendo que a seguir será detalhado como foi possível alcançar estes resultados.

\section{a) Redução de 13 para 3 modelos de caixa individual:}

Os produtos foram classificados em três grupos, levando em consideração suas dimensões externas aproximadas. Depois de definida a classificação, foram desenvolvidos três tipos de caixas individuais, sendo uma para cada grupo de produto, conforme descrito a seguir:

- Caixa Tamanho "P" - Para atender os produtos menores;

- Caixa Tamanho “M” - Para atender os produtos médios;

- Caixa Tamanho "G" - Para atender os produtos grandes.

Em que "P" significa pequeno, "M" médio e "G" grande.

b) Redução de 22 para 3 modelos de caixas coletivas:

Em relação às caixas coletivas, foram considerados três requisitos:

- Requito 01: capacidade máxima para 12 produtos por caixa;

- Requito 02: atender medidores embalados em caixas individuais;

- Requito 03: medidores separados por divisórias.

A figura 19 destaca os três tipos de requisitos de embalagens, que foram considerados como premissa no desenvolvimento do projeto. 


\begin{tabular}{|l|l|l|l|}
\hline Requisito 01 & \multicolumn{2}{|c|}{ Requisito 02 Requisito 03 } \\
\hline & & & \\
\hline
\end{tabular}

Figura 19 - Exemplo das embalagens conforme requisitos.

Diante dos requisitos definidos, foram criadas diversas divisórias para separar os produtos dentro da caixa coletiva, possibilitando a utilização de vários produtos na mesma caixa.

c) Redução de 23 conjunto de divisórias para 6 modelos de divisórias

A melhoria implementada que possibilitou a redução apresentada acima ocorreu devido à mudança realizada no processo de aquisição deste item, pois, deixou-se de comprar esse conjunto de divisórias que contemplava várias partes em um único código, para ser adquirida cada divisória de forma individual, sendo que na mesma foram inseridos vários cortes, em diferentes lugares da divisória.

A figura 20 mostra exemplos do conjunto de divisórias montado por meio de divisórias individuais.

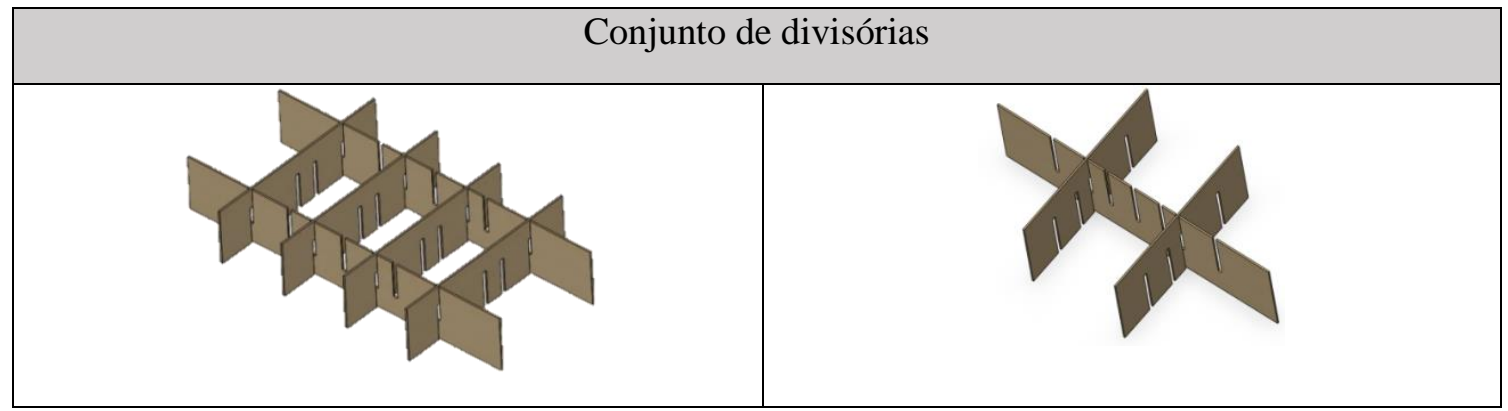

Figura 20 - Exemplos de conjunto de divisória e divisória.

Na figura 21 pode-se observar as disposições dos medidores dentro das caixas, separados por divisórias montadas conforme o tamanho do produto, mudando-se somente a posição do encaixe em cada divisória.

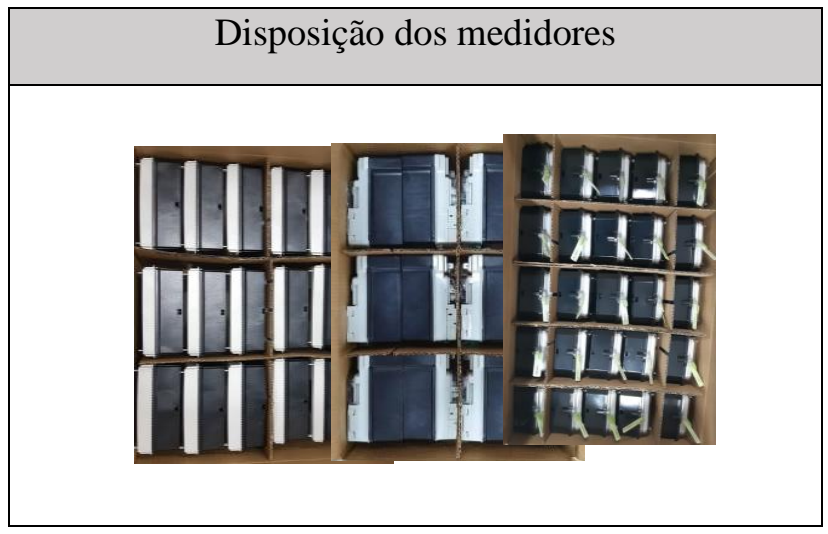

Figura 21 - Diferentes produtos na mesma caixa, separados por divisórias. 
Essa melhoria possibilitou utilizar diferentes produtos em uma mesma caixa, mudando somente a posição da divisória dentro da embalagem primária.

\subsubsection{Redução do custo de embalagem por lote de produtos.}

Com a realização do novo projeto, além dos resultados obtidos que já foram relatados anteriormente neste trabalho, houve outros ganhos que é importante dar destaque, sendo que um deles foi à diminuição do custo de embalagens gasto em reais, por lote de 1000 medidores. Isso foi possível por conta da mudança na especificação do papelão ondulado, pois, antes se utilizava nas embalagens coletivas e divisórias papelão ondulado com paredes duplas (onda BC) e nas individuais (onda B). Com a implementação do projeto passou-se a utilizar somente papelão ondulado com parede simples, mudando apenas o tipo de onda, no caso, as coletivas são fabricadas com papelão ondulado com onda tipo "C" e as individuais com onda tipo "E". Com isso, foi possível diminuir consideravelmente o custo por lote e mesmo assim atendendo perfeitamente aos requisitos determinados.

A seguir, na figura 22, serão demonstrados os ganhos obtidos comparados ao cenário anterior e com a realização do projeto.

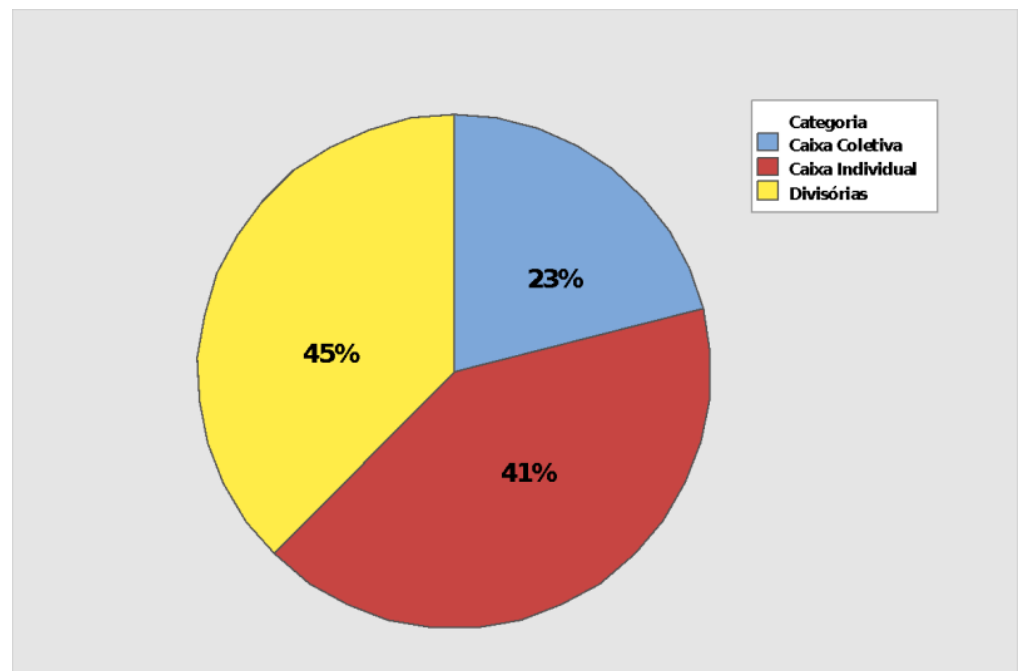

Figura 22 - Percentual de ganhos em reais por tipo de embalagem a cada lote de medidores, comprado ao custo do cenário anterior.

Fonte: Elaborada pelo autor (2019).

Pode-se observar na figura 22 os ganhos demonstrados em percentual, que foram obtidos por meio do projeto realizado, isso somente por lote de medidores fabricados, comparados ao mesmo cenário anterior ao projeto.

\subsubsection{Gerenciamento de Materiais.}

Com a padronização na utilização de embalagem para diferentes produtos da empresa estudada, houveram bastantes melhorias, principalmente na simplificação no gerenciamento do estoque, poder de barganha no ato da compra, planejamento de aquisição, ausência de dead stock no almoxarifado já que a mesma embalagem pode ser utilizada para diversos produtos e a facilidade no manuseio no processo produtivo. 


\subsubsection{Benefícios para o fornecedor.}

As melhorias obtidas com o projeto também beneficiaram o fornecedor parceiro na implementação do projeto estudado, pois com a padronização da utilização das embalagens, os pedidos de compra destes itens são em quantidades maiores e com menos variedade de itens, e isso diminui o tempo de setup para ajuste das máquinas. Outro ponto importante foi à credibilidade que o fornecedor teve com a empresa, pois essa atitude mostra que o mesmo visa o melhor para todos, ou seja, a relação ganha-ganha.

\section{CONCLUSÕES.}

A utilização de embalagens de forma padronizada pode ser decisiva para competitividade, principalmente em mercado bastante competitivo no qual a empresa objeto deste estudo está inserida, pois a maioria das vendas dos produtos deste segmento de mercado é são realizadas por meio de processo licitatório e cotações.

Esse trabalho apresentou uma metodologia capaz de padronizar as embalagens, possibilitando a redução da variedade de caixas individuais de treze itens para três, caixas coletivas de 22 itens para três e conjunto de divisórias de vinte e três itens para seis divisórias.

Para conseguir a obtenção da redução da variedade de itens de embalagens foram considerados alguns pontos relevantes durante a realização do projeto, primeiramente foi o levantamento dos requisitos dos clientes da organização estuda para que todos pudessem ser atendidos no projeto, a participação do fornecedor de embalagens ajudando no desenvolvimento do projeto orientando com sua expertise no assunto, o agrupamento dos produtos com dimensões semelhantes e a classificação das caixas coletivas e individuais nos tamanhos "P" para atender os produtos menores, "M" para atender os produtos médios e "G" para atender os produtos grandes.

Outro ponto observado que favoreceu bastante para o sucesso do trabalho apresentado foi à formação da equipe de forma multidisciplinar para realização do projeto, pois, cada membro desempenhou funções fundamentais durante a realização do projeto exemplo, o profissional da área comercial realizou o levantamento dos requisitos e na aprovação com os clientes , o da engenharia realizou os desenhos técnicos e as instruções operacionais para manuseios das novas embalagens, do suprimentos fez as cotações e comparações de preços, do almoxarifado fez o levantamento do estoque existente, da qualidade realizou as análises dimensionais e funcionais, do PCP programou a realização da fabricação do lote piloto, e os operações do setor de embalagens contribuíram informando quais as principais dificuldades encontradas no processo de embalagens e com sugestões para o projeto a ser desenvolvido.

A utilização de ferramentas da qualidade foi importante para busca dos resultados obtidos, pois, o brainstorming contribuiu para identificar as possíveis causas do problema, o fluxograma possibilitou saber em quais áreas da organização estudada as causas acontecem, com a matriz GUT foi possível analisar as causas que mais influenciava na ocorrência do problema a fim de priorizar as ações, os 5 Porquês apontou as causas raízes do problema e através da ferramenta $5 \mathrm{~W} 2 \mathrm{H}$ foram listadas e planejadas as principais ações para a resolução do problema analisado.

Antes da realização deste trabalho na empresa estudada, para cada novo produto desenvolviase uma embalagem especifica para o mesmo, não levando em consideração a possibilidade de utilização das embalagens existentes, o que favorecia para o aumento da variedade de itens de embalagens dentro da organização. 
Uma das razões para existir embalagens para cada produto, conforme já relatado neste estudo, deve-se pelo fato dos produtos possuírem dimensões externas distintas, neste caso, sugere-se que os gestores dos novos projetos ao desenvolver um novo produto, mantenham-se essas dimensões semelhantes ou aproximadas aos produtos atuais para que seja possível utilizar as embalagens que já existe, com isso evita-se o surgimento de novos itens de embalagens na empresa.

Durante a implementação do estudo, houve algumas limitações, como dificuldade de reunir todos os membros da equipe para discussão e alinhamento das ações a serem realizadas, sendo muitas vezes necessário o líder do projeto reunir somente pequenos grupos ou até mesmo conversar individualmente com membros que tinham pouca disponibilidade de agenda. Outra limitação deu-se pela dificuldade em motivar os membros da equipe e operadores envolvidos no processo de embalagens, destacando a importância e os benefícios que a empresa poderia alcançar com a execução do projeto, pois, ainda existem alguns colaboradores que quando são convidados para participar de projetos de melhorias em uma organização, pensam logo no que vai ganhar individualmente participando do projeto e não no resultado que todos possam alcançar.

Por fim, recomenda-se para estudos futuros que se faça a escolha correta do uso das ferramentas da qualidade conforme a aplicação a ser utilizada, pois isso tem uma importância significativa para o sucesso do trabalho.

O uso das ferramentas da qualidade foi bastante importante para busca dos resultados obtidos neste trabalho, no entanto, foi essencial a utilização correta das mesmas para que fosse encontrada a solução do problema analisado.

\section{REFERÊNCIAS}

ABNEE. Cenário para a indústria eletroeletrônica. Disponível em: <http://www.abinee.org.br/abinee/decon/dados/cesetora.pdf>. 2019.AGUIAR, M. C. (2014). Análise de Causa Raiz: levantamento dos métodos e exemplificação. Rio de Janeiro: PUC-Rio.

ASSOCIAÇÃO BRASILEIRA DE NORMAS TÉCNICAS. NBR 5985: embalagem de papelão ondulado - terminologia. Segunda Edição. 2008. NBR 5985

BASTOS, M. (2018). Ferramentas da Qualidade-Matriz Gut, 2014.

BEHR, A., MORO, E. L. D. S., \& ESTABEL, L. B. (2008). Gestão da biblioteca escolar: metodologias, enfoques e aplicação de ferramentas de gestão e serviços de biblioteca. Ciência da Informação, 37(2), 32-42

BIRRIEL ROLDAN, L. W. (2011). Brainstorming em prol da produtividade: um estudo de caso em três empresas de Varginha-MG. Revista Eletrônica de Iniciação Científica, 1(7).

CARPINETTI, L. C. R. (2012). Gestão da qualidade: conceitos e técnicas. 2a ed. São Paulo: Atlas.

CARVALHO, M. A. (2008). Engenharia de Embalagens: uma abordagem técnica do desenvolvimento de projetos de embalagens. Novatec.

DA SILVEIRA, H. E., MARTELli, R., \& DE OLIVEIRA, V. V. (2016). A implantação da ferramenta $5 \mathrm{~W} 2 \mathrm{H}$ como auxiliar no controle da gestão da empresa agropecuária São José. Revista de Administração do Sul do Pará (REASP)-FESAR, 3(2). 
DAYCHOUM, M. (2011). Ferramentas e Técnicas de Gerenciamento. Brasport. Rio de Janeiro GURGEL, F. A. (2007). Administração da embalagem. Thomson Learning.

GODOY, M. H. P. C. Brainstorming. Belo Horizonte: Editora de Desenvolvimento Gerencial, 2001.

HÉKIS, H. R., DA SILVA, Á. D. C., DE OLIVEIRA, I. M. P., \& DE FRANÇA ARAUJO, J. P. (2013). Análise GUT e a gestão da informação para tomada de decisão em uma empresa de produtos orgânicos do Rio Grande do Norte. Revista Tecnologia, 34(1/2), 20-32.

MAICZUK, J., \& JÚNIOR, P. P. A. (2013). Aplicação de ferramentas de melhoria de qualidade e produtividade nos processos produtivos: um estudo de caso. Qualitas Revista Eletrônica, 14(1).

MARTINS, R. Fluxograma de Processo. Disponível em: http://www.blogdaqualidade.com.br/fluxograma-de-processo/.

MEGNA, D. S. L., BRITO, G., \& SANTOS, R. (2016). Aplicação das ferramentas da qualidade em processo logistíco de uma empresa do ramo petrolífero. Encontro Nacional de Engenharia de Produção, 36

MELLO, A. E. N. S. D. (2008). Aplicação do mapeamento de processos e da simulação no desenvolvimento de projetos de processos produtivos.

MOURA, R. A., \& BANZATO, J. M. (1997). Embalagem, unitização \& conteinerização. Imam.

ONDULADO, Site Papelão. Tipos de Papelão Ondulado: Tipos de Ondas. 2019. Disponível em: $<$ https://papelaoondulado.wordpress.com/tag/tipos-de-papelao/>.

PEREIRA, J. (2016). Artigo ABPO: Composição da chapa de papelão ondulado. O Papel: revista mensal de tecnologia em celulose e papel, 77(2), 81-81.

ROCHA, F. M. D. (2015). Padronização e Otimização do embalamento na cadeia de abastecimento.

SOARES, S. C.; BRITO, J. N. Análise da causa raiz da falha de um moinho de pinos utilizado no processo produtivo de uma indústria processadora de amêndoa de cacau. In: XXXIV Encontro Nacional de Engenharia de Produção. Anais... Curitiba, 2014.

THIOLLENT, M., \& DE OLIVEIRA SILVA, G. (2007). Metodologia de pesquisa-ação na área de gestão de problemas ambientais. Revista eletrônica de comunicação, Informação e Inovação em Saúde, $1(1)$.

VIDAL, A. C. F. (2012). O mercado de papelão ondulado e os desafios da competitividade da indústria brasileira. BNDES Setorial, n. 35, mar. 2012, p. 5-46. 